\title{
軸状集光ビーム生成におけるアクシコンの傾きの影響
}

\author{
松岡 芳彦 ${ }^{1}$, 井上 尚志 ${ }^{1}$, 木塚 優子 ${ }^{1}$, 山内 真 ${ }^{1}$, 丸山 伸吾 ${ }^{2, \dagger}$, 木下 岳司 ${ }^{2}$ \\ 1産業技術総合研究所（テ305-8564 茨城県つくば市並木1-2-1 産総研東） \\ 2慶應義塾大学（干223-8522 神奈川県横浜市港北区日吉3-14-1）
}

\section{Influence of Axicon Tilt in Axially Condensed Beam Generation}

\author{
Yoshihiko MATSUOKA, ${ }^{1}$ Takashi INOUE, ${ }^{1}$ Yuko KIZUKA, ${ }^{1}$ Makoto YAMAUCHI, ${ }^{1}$ \\ Shingo MARUYAMA, ${ }^{2, \dagger}$ and Takeshi KINOSHITA ${ }^{2}$ \\ ${ }^{I}$ National Institute of Advanced Industrial Science and Technology (AIST), \\ Tsukuba East, Namiki 1-2-1, Tsukuba, Ibaraki 305-8564 \\ ${ }^{2}$ Keio University, Hiyoshi 3-14-1, Kohoku-ku, Yokohama, Kanagawa 223-8522
}

(Received February 18, 2005)

\begin{abstract}
Axially condensed beams exhibit properties suitable for laser micro-fabrication. The influence of axicon tilt was examined when an axially condensed beam was formed using an axicon. For both types of axicons, conical shape glass lens and binary diffractive optical element (DOE), the ideal axially condensed beam profile is kept below a tilt angle of less than about $5^{\circ}$. The beam generation using an axicon does not need precise alignment. However, with the conical shape glass axicon, the symmetry axis of the cone and the undersurface should be orthogonal within an angle error margin of 1', for axially condensed beam generation. This is the first report to present laser drill performance using a DOE axicon.
\end{abstract}

Key Words: Axially condensed beam, Axicon, Diffractive Optical Element (DOE), Beam alignment, Laser drilling

1.はじめに

微細加工の需要が高まるなかで，レーザー加工への期 待は益々大きくなってきている．従来の機械的工具によ る接触を伴う加工は，例えば刃先の形状が加工時間の累 積とともに変化していくため(磨耗), その形状変化が無視 できなくなるような微細な加工サイズ領域では, 加工の 寸法制御が困難となる。また，粗加工から仕上げ加工へ と除去量や加工精度が変化するにつれて加工工具を取り 換える必要があり，従来の機械的加工では維持管理しな ければならない「刃」などの工具は膨大な量である。これに 対して，レーザー加工は非接触であるために工具磨耗の 問題から解き放たれるとともに，集光状態やエネルギー の調整によって除去量や加工精度が制御できるために「刃」 に相当する工具の取り換えすら不要になる。このように レーザー加工は微細加工に非常に適した特性を有する。 一方で, 従来的なレーザーによる「熱的」加工で生じる変質 や変形といった熱影響や発生するドロスなどは微細加工 では無視できなくなり，また利用しようとする集光ス ポットサイズが波長と比較し得る程度となると集光およ
びその状態の維持が急に難しくなるという問題がある.

微細加工におけるレーザー加工の熱影響の問題は, 適 切なレーザー発振器の選択を中心に検討が行われてい る。その一つは，熱として吸収される赤外線レーザーに 代えて，材料を構成する元素間の化学結合を直接に切断 することができる紫外線レーザー，例えばエキシマレー ザーや，Nd:YAGレーザーなどの第3高調波や第4高調波を 用いることである11. また超短パルス幅の光を出力する レーザー発振器, 即ちフェムト秒レーザーの選択も効果 がある2,3). 材料に照射された光エネルギーは, 最初に材 料を構成する元素の電子に受け取られ，ピコ秒程度の時 間をかけて格子振動(即ち熱)へと姿を変えていく. 照射さ れるレーザーのパルス幅がナノ秒よりも長いと, 一つの パルスの終わりの部分が照射される頃には，そのパルス の始まりの部分のエネルギーが照射された材料に熱とし て現れてしまうために，熱影響を避けることが難しい. 一方レーザーのパルス幅がフェムト秒領域となると，照 射するエネルギーを加工に必要な量に適切に調節してや れば，照射した光のエネルギーが熱に変わる前に加工は 完了し，また余剩のエネルギーが熱に変わることも無い

†現在の所属：凸版印刷(株) 
ので，熱影響の大幅な低減が期待できる.

光学的に不透明な材料の内部のミクロンサイズの微細 加工に, ワークディスタンスの精密制御なしに利用でき るビームの検討は，あまりなされてこなかった。我々 は, McLeodにより詳細に検討された軸状集光4), また軸 状集光の一種であり Durninにより非回折ビームとして報告 されたBesselビーム5,6) に着目して研究を行ってきており, これまでに，このビームが微小スポットサイズと長焦点 深度を両立したレーザー微細加工に適したビームである ことを数值計算により示した7). またナノ秒パルスのレー ザー光源を用いた実験により，ミクロンサイズの点加工 およびミクロンサイズの開口径で高アスペクト比の円柱 形状のドリル加工を，ワークディスタンスの精密制御なし に，このビームを用いて実施できることを実証した8,9).

従来の凸レンズ集光は, 微細な集光スポットを形成す るには高開口数集光である必要があり, そのような場合 にはレンズとビームのアライメントに精密さが要求され ることが知られている。我々は先の論文で, 互いに平行 位置関係にある軸状集光素子(アクシコン)の光学軸とレー ザービームの中心軸との軸間距離と生成される軸状集光 ビームの特性について数值検討し, 軸間距離がレーザー ビーム (ガウシアン)半径の $25 \%$ 程度以内であれば生成さ れる軸状集光ビームの集光スポット径も伝播軸上強度分 布も変化せずに安定であることを報告した7)。本報では， 軸状集光ビームの生成におけるアクシコンの傾きの及ぼ す影響について, 円錐形状レンズと透過型回折光学素子 (DOE)の二つの型のアクシコンの場合の実験結果を報告 する.またあわせて, 円錐形状アクシコンの円錐対称軸 と円底面の直交度が軸集光ビームの生成に及ぼす影響, 透過型DOEアクシコンを用いて生成した軸状集光ビーム によるドリル実験結果も報告する。

\section{2. 透過型DOEアクシコンの試作}

円錐形状アクシコン (波長入における屈折率 $n_{\mathrm{a}}$ ) の円底面 にコリメートされたコヒーレント光を垂直に入射させる と, 光線は円錐面で屈折を受け, 伝播軸と角度 $\theta_{\mathrm{b}}$

$$
\theta_{\mathrm{b}}=\theta_{\mathrm{a}}-\arccos \left(n_{\mathrm{a}} \cos \theta_{\mathrm{a}} / n_{0}\right)
$$

を成して交わる7)。ここで， $\theta_{\mathrm{a}}$ は円錐の半頂角， $n_{0}$ は空気 の屈折率である。この円錐形状アクシコンと同じ回折機 能を有するバイナリーの透過型DOEアクシコンは, ピッ チムが

$$
\Lambda=\lambda / \sin \theta_{\mathrm{b}}
$$

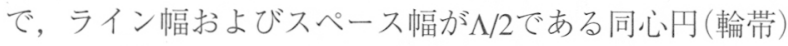
である、

試作したDOEアクシコンは, 半頂角が $88^{\circ} の$ 合成石英ガ ラス製円錐形状アクシコンと同じ回折機能を有するもの であり, 波長 $\lambda=532 \mathrm{~nm}$, 合成石英ガラスの屈折率 $n_{\mathrm{a}}=$ 1.46 として, $\Lambda=33.0 \mu \mathrm{m}$ である. 合成石英ガラス製平行 円平板 $(25 \mathrm{~mm} \phi$, 厚さ $4 \mathrm{~mm})$ に電子線用ポジ型レジスト ZEP520A (日本ゼオン社製) を厚さ約 $400 \mathrm{~nm}$ でスピンコー
トし, 最外径が $6 \mathrm{~mm} \phi$ の同心輪帯パターンを電子線描画 (エリオニクス社製電子線描画装置ELS7500H, 加速電圧 $100 \mathrm{kV}$, ビーム電流 $0.32 \mathrm{nA}$, 照射量約 $\left.160 \mu \mathrm{C} / \mathrm{cm}^{2}\right)$ した。 なお，描画フィールドサイズは600 $\mu \mathrm{m} \times 600 \mu \mathrm{m}$ であり， そのつなぎ精度は40 nm以内である。描画後, 現像して DOEアクシコンを得た。試作したDOEアクシコンの光学 顕微鏡写真をFig. 1に示す。暗い部分は電子線が照射され た部分であり，現像によってレジストが除去されてい る. 理論から示される試作したバイナリー透過型DOEの 最大 1 次回折効率は $40.5 \%$ であり, 溝深さが最適でない場 合は回折効率が低下する ${ }^{10)}$. 試作したDOEアクシコンで は，レジストの厚さが少々不足しており，軸状集光ビー ム生成に寄与する成分の回折効率は約 $30 \%$ \%市った。

\section{3. 実 験}

軸状集光ビームの生成におけるアクシコンの傾きの影 響は，光源にHe-Neレーザーを用い，ビームエキスパンダ を用いて径を拡大しさらにコリメートしたビームをアク シコンに入射させ, 生成した軸状集光ビームの光強度分 布を拡大観察光学系を通してビームプロファイラ (浜松ホ トニクス製LEPAS-11)で観察した。用いたアクシコンは, 合成石英ガラス製円錐形状アクシコン (半頂角 $88^{\circ}$, 円錐 対称軸と円底面法線のなす角度 $<1$ ') と試作したDOEアク シコンである. Fig. 2に示すように, 円錐形状アクシコン の場合には円底面側から He-Neレーザーを入射させ，円底 面の法線と入射するHe-Neレーザーの伝播軸のなす角度を 入射角 $\theta_{\mathrm{i}}$ とした。またDOEアクシコンの場合には回折格子 の形成されていない面側から入射させ，入射面の法線と 入射ビームのなす角度を入射角 $\theta_{\mathrm{i}}$ とした。

円錐形状アクシコンの円錐対称軸と円底面の直交度が 軸集光ビームの生成に及ぼす影響は, 合成石英ガラ又製 円錐形状アクシコン (半頂角 $87^{\circ}$, 円錐対称軸と円底面法 線のなす角度 2'48”) の円底面にHe-Neレーザーを垂直に入 射させ, 生成されるビームの光強度分布を, 同様に拡大 観察光学系を通してビームプロファイラで観察した。

円錐形状と, DOEアクシコンのレーザーマイクロドリ

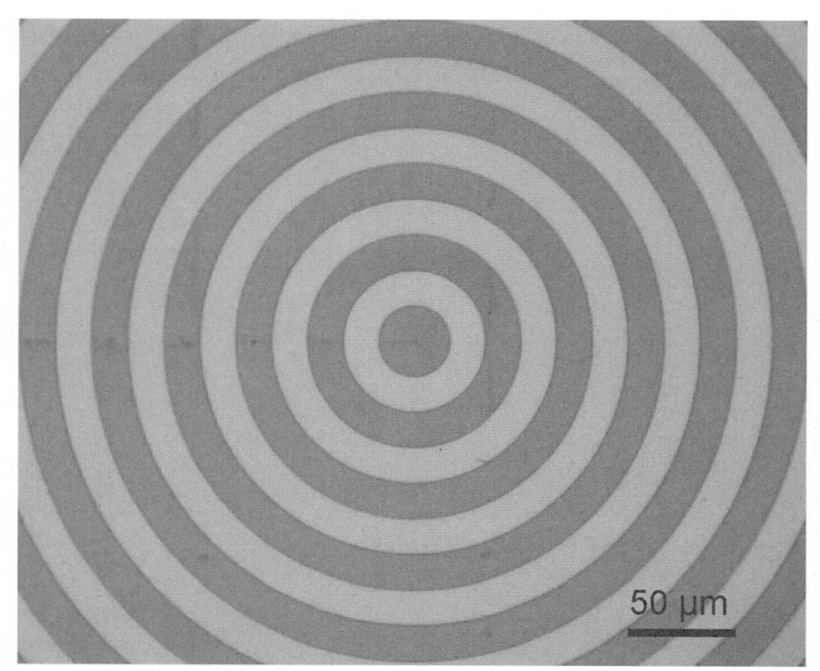

Fig. 1 Optical microscope view of DOE axicon.

レーザー研究 2005 年 9 月 
(a)

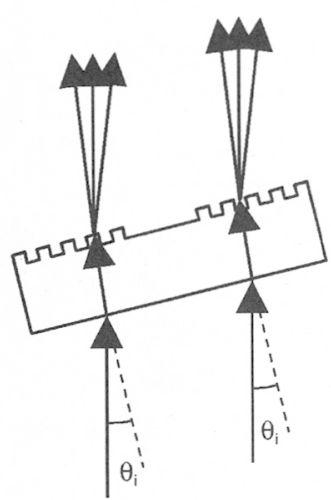

(b)

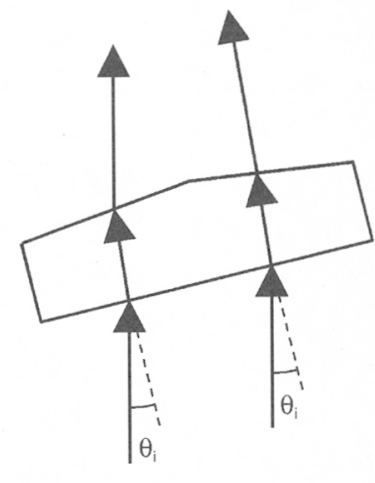

Fig. 2 Incident angle $\theta_{i}$ to axicon. ((a): DOE axicon, (b): Cone axicon).

ルの比較実験は，合成石英ガラス製円錐形状アクシコン (半頂角 $87.5^{\circ}$, 円錐対称軸と円底面法線のなす角度 $<1^{\prime}$ ) と試作したDOEアクシコンを用いて，Fig. 3の実験配置で

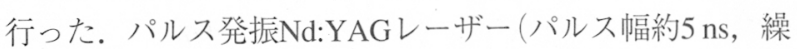
返し周波数 $10 \mathrm{~Hz}$ ) の第二高調波(波長 $532 \mathrm{~nm}$ ) を光源に用 いた。厚さ2 $0 \mu \mathrm{m}$ のSUS304箔の試料は, x-y-zステージ上 に置かれ(大気雲囲気中), 試料表面にほぼ垂直に軸状集光 ビームは照射される．Nd:YAGレーザーは実験を通して一 定の条件で発振をしており, 発振器とアクシコンの間に 機械的シャッターと適切なNDフィルターが挿入され, 試 料へ照射されるレーザー光の強度はNDフィルターによっ て，照射する光パルス数はシャッターの開放時間により 調節する。特に本実験では, 虹彩絞りを用いて光源から のビームの中心部の直径 $6 \mathrm{~mm} \phi$ を切出し, 切出したビーム の中心をアクシコンの対称中心に一致させてアクシコン の底(裏)面に垂直に入射させた。

\section{4.結果および考察}

円錐形状アクシコン (半頂角 $88^{\circ}$, 円錐対称軸と円底面 法線のなす角度 $<1$ ') および試作したDOEアクシコンの底 (裏)面にHe-Neレーザーを， $0^{\circ} ， 6.5^{\circ}, 9^{\circ}$ の人射角 $\theta_{\mathrm{i}}$ で入 射させた場合の, 観測された軸状集光部の光強度分布を Fig.4に示す。垂直入射の場合 (DOEアクシコン：(a)DOE/ $0^{\circ}$, 円錐形状アクシコン：(d)Cone $/ 0^{\circ}$ ), どちらも軸状集 光ビームの一種であるBesselビーム特有の同心円(輪帯)の

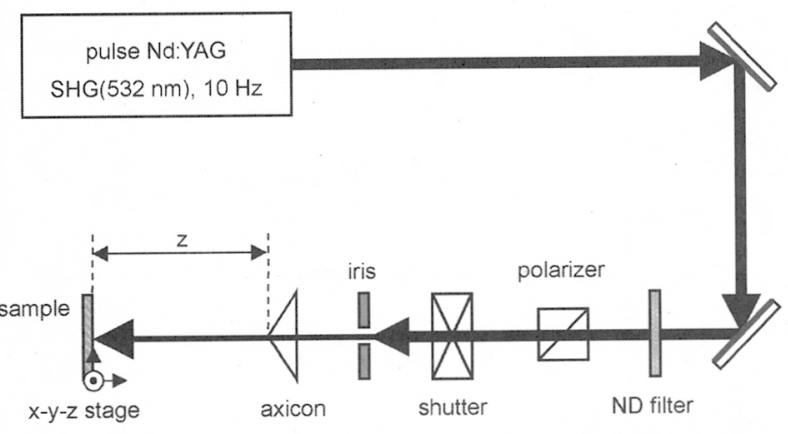

Fig. 3 Experimental setup of laser drilling.
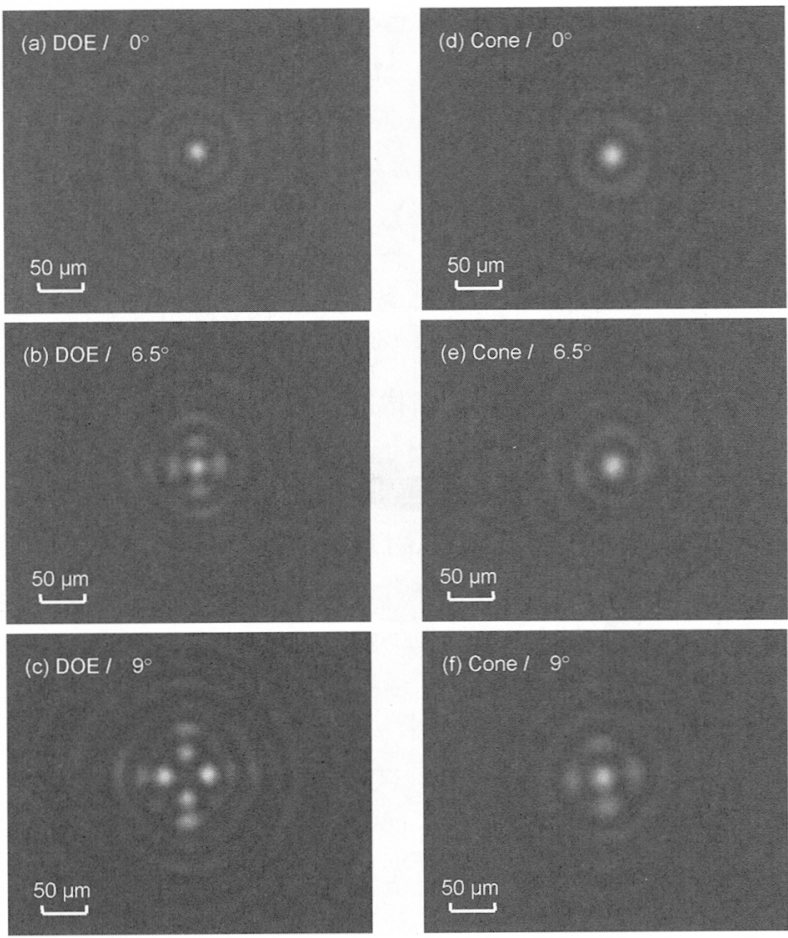

light intensity [arb. units]

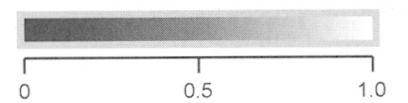

Fig. 4 Change of light intensity distribution at the focal area depending on the incidence angle. (DOE axicon: (a) $0^{\circ}$, (b) $6.5^{\circ}$, (c) $9^{\circ}$. Cone axicon: (d) $0^{\circ}$, (e) $6.5^{\circ}$, (f) $9^{\circ}$.).

強度分布が得られている。試作したDOEアクシコンは, ここで比較評価している合成石英ガラス製の円錐半頂角 が $88^{\circ}$ のアクシコンと同じ集光機能を目標に設計された が, Fig. 4 (a)，(d)の比較から明らかなように同心輪帯の 半径の周期が試作したDOEアクシコンの集光部の強度分 布の方が短くなっている。このことは屈折率の值が，実 際の合成石英ガラスと計算に用いたものとで, $0.1 \%$ 程度 異なっていたことが理由と考えられる。

1954年のMcLeodのアクシコンに関する論文4)の後, 1962年にFujiwaraは点光源の反射型円錐面による結像につ いて理論と実験の両面から検討し, 結果を報告してい る11). Fujiwaraの論文のFig. 6に明確に示されているよう に, 円錐の対称軸上に点光源がある (on-axis)場合は円錐面 で反射した後に同心輪帯の光強度分布の結像が得られる が，点光源が円錐の対称軸上に無く (off-axis), 点光源と 円錐頂点とを結ぶ線が円錐対称軸となす角度が大きくな るに従い, 0次の中心ロブ強度が減衰して1次のサイドロ ブが輪帯から円周上の等間隔の4つの点へと変化する。更 に斜入射の角度が大きくなると, 高次のサイドロブも輪 带から複数の点へと変わっていく.

我々が検討しているのは透過型アクシコンへのコリ メート光の入射であり, Fujiwaraの論文は反射型アクシコ ンへの点光源から発した光の入射であるという違いはあ るが，Fujiwaraの報告した斜入射角度変化による結像パ ターンの変化と同様の変化が, 我々の結果 (Fig. 4)にも現 れている，我々の試作したDOEアクシコンの場合，約 
$6.5^{\circ}$ の斜入射で1次のサイドロブが4つの点へと変化し, 更 に約 9 の斜入射で 0 次の中心ロブがその強度を殆ど失い, 高次のサイドロブ(輪帯) も点へと変化している。 DOEア クシコンとほほ同じ伝播軸との交差角 $\theta_{\mathrm{b}}$ を持つ半頂角 $88^{\circ}$ の円錐形状アクシコンの場合, 約 $6.5^{\circ}$ の斜入射でも同心輪 帯の強度分布が維持されており, 約 $9^{\circ}$ の斜入射でやっと 1次のサイドロブが輪帯から点へと変化し始めている。実 用において重要であるのは, 集光部の光強度分布が同心 輪帯に保たれていれば，軸状集光ビームの光強度の高い 中心ロブを微細集光スポットとして加工に用いることが できることである. Fig. 4から，DOEおよび円錐形状のど ちらのアクシコンも, 斜入射角度が約 5 ○以内であれば集 光部の光強度分布を同心輪帯に保つことができると考え られる，実際において平面への垂直入射は最もアライメ ントが容易なものであり，適当に行ったとしても $5^{\circ} も の$ ずれは生じない．先の軸ずれの許容に関する検討の報告7) と本実験結果から，「アクシコンを用いた軸状集光ビーム の生成は，微細な集光スポットを形成できるものであり ながら，従来の凸レンズ集光のように厳密なレンズと入 射ビームのアライメントを要求しない。アクシコン底面 への斜入射は約 5 程度まで，またアクシコンの軸に平行 にビーム (ガウシアン)が入射する場合の両軸のずれは入射 ビーム半径の約 $25 \%$ 程度まで許容される」とまとめること ができる。

DOEアクシコンに用いる基板は，工業的に安定に量産 されている平行平板であり, 形状の不安定要因とはなり 難い。一方, 円錐形状アクシコンの場合は, 円底面と円 錐面の対称軸の直交性が満足されない場合が懸念され る. 円底面と円錐面の対称軸が直交していないアクシコ ンの円底面にビームを垂直入射させた場合，入射ビーム は円底面を真っ直ぐに通過した後，円錐面に斜入射する ことになる．Fig. 5に，合成石英ガラス製円錐形状アクシ コン (半頂角 $87^{\circ}$, 円錐対称軸と円底面法線のなす角度 2’48”) の円底面にHe-Neレーザーを垂直に入射させた場合 の, 観測された軸状集光部の光強度分布を示す。驚くべ きことに，僅か2'48”の角度ずれ(円底面と円錐面の対称軸 の直交からのずれ)で1次のサイドロブが4つの点に変化し てしまっている. 同様の軸状集光部の光強度分布の変化
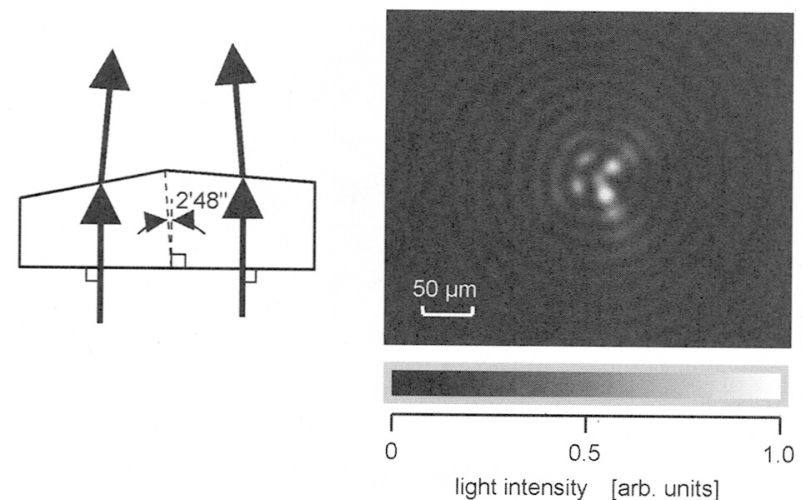

Fig. 5 Light intensity distribution at the focal area by cone axicon for which the symmetry axis of the cone and the undersurface is orthogonal with the angle error of 2' 48 '”.
は, 半頂角 $77.5^{\circ}$, 角度ずれ 2 '26”の合成石英ガラス製円錐 形状アクシコンなどでも観測された。一方角度ずれを 1 , 以 内に抑えた幾つもの円錐形状アクシコン ((半頂角 $74^{\circ}$, 角 度ずれ $\left.1^{\prime} 00^{\prime \prime}\right)$, (半頂角 $77.5^{\circ}$, 角度ずれ 0 ' $26^{\prime \prime}$ ), (半頂角 $77.5^{\circ}$, 角度ずれ $\left.0^{\prime} 34^{\prime \prime}\right)$, (半頂角 $77.5^{\circ}$, 角度ずれ 0 ' $52^{\prime \prime}$ ), (半頂角 $80^{\circ}$, 角度ずれ $0^{\prime} 15^{\prime \prime}$ ), (半頂角 $85^{\circ}$, 角度ずれ $\left.0^{\prime} 31^{\prime \prime}\right)$, (半頂角 $87.5^{\circ}$, 角度ずれ0’38”), (半頂角 $88^{\circ}$, 角 度ずれ0'57”))を試作し，円底面へビームを垂直入射させ て評価した結果，いずれも同心輪帯の軸状集光部の光強 度分布が得られた。従って, 微細加工用の軸状集光素子 としての円錐形状アクシコンは, 円底面と円錐対称軸の 角度ずれを少なくとも1’以内に抑える必要がある。

DOEの方が円錐形状よりも斜入射の影響を早くに受け て，集光部の光強度分布が同心輪带から変化し始める理 由，および円錐対称軸と円底面の直交性が満足された円 錐形状アクシコンの場合は円底面への約 5 にも及ぶ斜入 射でも集光部の同心輪带の強度分布が維持されるのに対 して円錐対称軸と円底面の角度ずれは僅か 1 '程度しか許さ れない理由は現時点では分からないが，実形状に基づく 干涉パターンの入射角依存を数值解析することにより明 らかになると思われる。

出力が高い加工用レーザーへの回折型光学素子の集光 素子としての適用は, 損傷の発生などが懸念され，行わ れてこなかった。我々は試作したDOEアクシコンにより 生成される軸状集光ビームを用いてレーザードリル加工 を実施し，その結果を従来の円錐形状アクシコンを用い

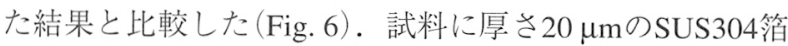
を用い，パルスエネルギーを変化させ，貫通に要した照 射パルス数を計測した。貫通は, 試料裏面からドリルに 用いている532 nmの光が漏れ始めたことを目視により確 認・判断した。試作したDOEアクシコンの場合は，アク シコンー試料間距離 $135 \mathrm{~mm}, 6 \mathrm{~mm} \phi$ の入射ビーム直径 で, $0.5,1.0,2.5 \mathrm{~mJ} / \mathrm{pulse}$ のつのパルスエネルギーでそ れぞれドリル加工を実施した。円錐形状アクシコンは, 試作したDOEアクシコンと集光部の同心輪帯の周期がよ り近いものとして半頂角が $87.5^{\circ}$ ののを用い, アクシコ ン一試料間距離 $105 \mathrm{~mm}, 6 \mathrm{~mm} \phi$ の入射ビーム直径で, $0.1, \quad 0.25, \quad 0.5,1.0 \mathrm{~mJ} / \mathrm{pulse}$ のつのパルスエネルギーでそ

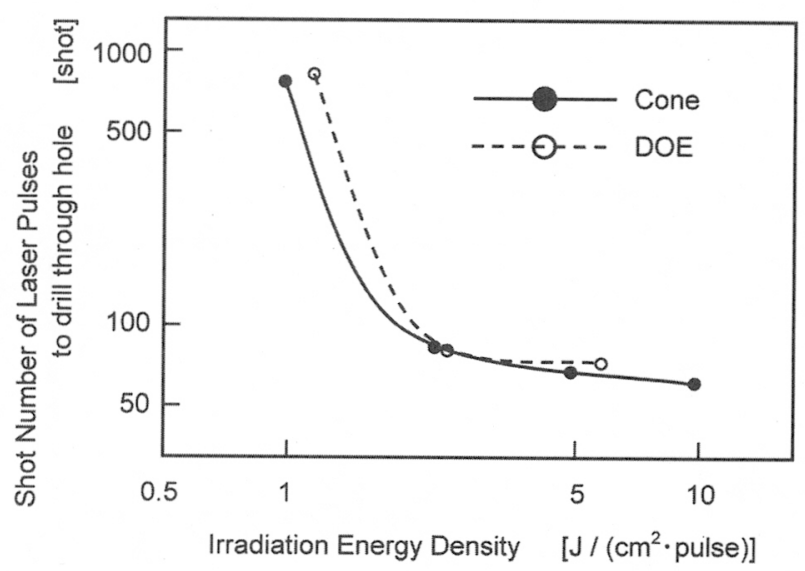

Fig. 6 Dependency of laser pulse shot number for drill through hole on irradiation energy density. 
れぞれドリル加工を実施した。加工点における軸状集光 ビームの中心ロブの $1 / \mathrm{e}^{2}$ 直径内の平均エネルギー密度を数 值計算し，Fig.6の横軸に用いた。但し，DOEアクシコン の場合は回折効率を考慮して，入射パルスエネルギーの 約 $30 \%$ \%゙軸状集光ビーム形成に利用されたものとした.

Fig. 6に示されている, 貫通穴形成に要する照射パルス数 の照射エネルギー密度依存は, 円錐形状アクシコンと試 作したDOEアクシコンとでよく一致しており，ほぼ同じ 軸状集光ビームが形成できていると考えることができ る. どちらも加工点での照射エネルギー密度が高いと貫 通に要するパルス数変化は緩やかであり, 照射エネル ギー密度が小さくなると貫通に要する照射パルス数は急 に増加する。

我々が試作したDOEアクシコンはレジストを現像した だけのものであり, 従来のレーザー加工の出力領域では 直ぐに損傷を受けてしまい実用的でないと考えられてき た。しかしながら，微細加工分野では集光スポットの大 きさが $1 \times 10^{-6} \mathrm{~cm}^{2}$ 程度と極めて小さいので, 加工点でレー ザーアブレーションに必要な照射エネルギー密度 (数 $\left.\mathrm{J} / \mathrm{cm}^{2}\right)$ を達成するために, 集光素子に大きな光エネルギー を通過させる必要はない. 我々の実験でDOEに入射させ

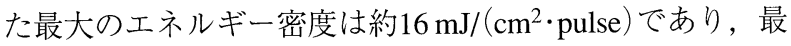
大エネルギー密度で約6分間 (3,600ショット)の入射後も, 形成される軸状集光ビームに変化は見られなかった。

\section{5. まとめ}

レーザー微細加工用のビームとして高い適性を有する と考えられる軸状集光ビームを，アクシコンを用いて形 成する際に許容されるアクシコンの傾きについて, 円錐 形状と試作したDOEの二つのアクシコンの場合を実験検 討した。 どちらのアクシコンの場合もアクシコン底面へ
の5 程度の斜入射角度が許容されており，凸レンズ集光 に比べてアライメントの厳密さを要求されない。

円錐形状アクシコンの場合，円錐対称軸と円底面との 直交からのずれが僅か3 3 程度で，軸状集光部の中心ロブの 消失が観測された，微細加工用の軸状集光ビームを安定 に形成するためには，円錐形状アクシコンの円錐対称軸 と円底面の直交からのずれは少なくとも1'以内である必要 がある。

試作したDOEアクシコンはレジストを現像しただけの ものであるが，レーザーマイクロドリル加工実験に適用 できた。

\section{謝 辞}

円錐形状アクシコンの円錐対称軸と円底面の直交度の 評価, および直交度の高い円錐形状アクシコンの試作に ご協力いただいた，夏目光学(株)殿に深く感謝いたしま す.

\section{参考文献}

1）杉岡 幸次：レーザー研究 30 (2002) 226.

2) 邱 建栄, 平尾一之：レーザー研究 30 (2002) 233.

3) 三澤弘明：レーザー研究 30 (2002) 239.

4) J. H. McLeod: J. Opt. Soc. Am. 44 (1954) 592.

5) J. Durnin, J. J. Miceli, Jr., and J. H. Eberly: Phys. Rev. Lett. 58 (1987) 1499.

6) J. Durnin: J. Opt. Soc. Am. A4 (1987) 651.

7）松岡 芳彦：レーザー研究 32 (2004) 131

8) M. Kohno and M. Matsuoka: JSME Int. J. B 47 (2004) 497.

9）松烊芳彦，河野正道：レーザー研究 32 (2004) 348.

10）塩野照弘：「レリーフ型回折光学素子の回折効率」回折光学 素子入門 (社) 応用物理学会日本光学会光設計研究グループ監 修（オプトロニクス社，1997）63-73.

11) S. Fujiwara: J. Opt. Soc. Am. 52 (1962) 287. 